\title{
The effects of rapid chilling and storage conditions on the quality of Brigitta Blue cultivar highbush blueberries (Vaccinium corymbosum L.)
}

\author{
Karolina Kozos*, Ireneusz, Ochmian, Piotr Chelpiński
}

Department of Horticulture

West Pomeranian University of Technology in Szczecin Słowackiego 17, 71-434 Szczecin, Poland

\begin{abstract}
Controlled atmosphere storage allows for the long-term and short-term storage of fruit without a significant decrease in quality, resulting in a longer shelflife of fresh fruit. The Department of Horticulture at the West Pomeranian University of Technology in Szczecin conducted research on the effects of post-harvest precooling $\left(3-4^{\circ} \mathrm{C}\right.$ within two hours) and storage conditions (conventional cold room and controlled atmosphere storage) on fruit firmness, chemical composition, colour and weight loss.

After six weeks of storage, it was found that the quality of fruit had declined. In comparison with fresh fruit, the harvest was found to have lost weight and darkened in colour. In addition, a decrease in firmness and the content of ascorbic acid and polyphenolic compounds was also observed. The fruits that were stored in a cold room with a controlled atmosphere and rapidly chilled immediately after harvest were the least affected. In addition, the research showed that there was a high correlation between the anthocyanin index and the polyphenol content in the fruits. To maintain the high quality of the fruit, the fruit must be very rapidly cooled soon after harvest and stored under optimal conditions - a cold room with a controlled atmosphere.
\end{abstract}

Key words: colour, firmness, shock-cooling, storage, controlled atmosphere, Vaccinium

\section{INTRODUCTION}

Highbush blueberry is mainly grown in Chile, Canada, the USA, Australia and New Zealand. Blueberry plantations can also be found in Europe, especially in Poland (Strik 2005). Acid peat soils with low $\mathrm{pH}(3.5-4.0)$ values and a stable groundwater level are especially recommended for the cultivation of this cultivar (Moore 1993).

Berry size is of decisive importance for the consumer in choosing the product and for further use of the fruit. The main factors affecting the fruit quality are: cultivar, climate, growing conditions and degree of ripeness, but there are many other considerations that need to be taken into account. (Remberg et al. 2006, Skupień et al. 2009). The choice of a cultivation technique affects the ripening season. It has been observed that fruits grown at organic plantations ripened later and contained higher levels of potassium, copper and iron, as well as nitrogen and phosphorus (Ochmian 2013). Fruits with a higher calcium content are characterised by greater firmness (Fallahi et al. 1997), which is an indicator of fruit quality, and therefore of fruit freshness. This is an important quality indicator, 
especially after the storage period. Rapid cooling (pre-cooling) of the fruits soon after harvest has a positive effect on their firmness (Ochmian et al. 2015 in press). The increased content of $\mathrm{CO}_{2}$ and lower $\mathrm{O}_{2}$ reduces yield losses, especially the crop mass during storage (Alsmairat et al. 2011). Losses are much smaller in CA cold rooms in comparison with ordinary ones (Chiabrando et al. 2009). It is recommended that the $\mathrm{CO}_{2}$ partial pressure be maintained between 8 and $15 \mathrm{kPa}$ and $\mathrm{O}_{2}$ levels are maintained above 2 to $4 \mathrm{kPa}$. The content of anthocyanins in the fruit also depends on the conditions in which it is stored, and its physiological state (Häkkinnen et al. 2000).

There are difficulties in ensuring that fresh fruit is transported on a regular basis, especially over long distances, and is in constant supply. As a result, serious damage and losses occur, which may be mitigated by reducing the risk associated with handling the goods by ensuring suitable packing and cooling conditions at the premises of the producer immediately after harvest, in addition to providing suitable storage conditions. The technique of rapid chilling is used for the treatment of fruits, including in particular berry fruits, immediately after harvest to ensure that the heat of the freshly harvested fruit is absorbed and the respiration rate, which causes the production of a significant amount of heat, is reduced to a minimum. Increasingly, the technique of vacuum cooling is used, which involves the rapid evaporation of water from the fruit in a relatively short time (Wang and Sun 2001).

Fruits stored under controlled atmospheric conditions, especially with a low oxygen content, show a higher quality and more favourable chemical composition, including higher free radical (DPPH) scavenging capacities, than fruits stored in a conventional cold room (Krupa and Tomala 2006).

The aim of the research was to investigate how the method of preparation for storage (shock-cooling after the harvest) and storage conditions (normal and controlled atmosphere) can affect the quality of 'Brigitta Blue' highbush blueberries, their physical characteristics and chemical composition.

\section{MATERIAL AND METHODS}

The studies were carried out in the Orchard Laboratory at the Department of Horticulture of the West Pomeranian University of Technology in Szczecin (Poland). Fruits of the Brigitta Blue cultivar were harvested at the stage of consumption maturity. Both the shock-cooled berries (temperature drop to $3-4^{\circ} \mathrm{C}$ ) and not shock-cooled berries were then stored in a cold room with a controlled atmosphere $(15 ; 5)$ or in a normal atmosphere. Berries were stored for six weeks at temperature of $2 \pm 0.2^{\circ} \mathrm{C}$ and relative air humidity of $95 \%$. The experiment was performed in five repetitions, each for $1.25 \mathrm{~kg}$ of berries.

Scheme of the experiment:

- 2 methods of fruit storage - normal atmosphere and controlled atmosphere (CA),

- 2 methods of sample preparation - without shock cooling and shock cooling.

The experiment was conducted at a 60 ha production plantation located in the area of Szczecin. Blueberry bushes were planted at a spacing of 2.0 $\times 1.2 \mathrm{~m}$ in podzolic soil of the VI valuation class.

The physical features of fruits (puncture of the skin and firmness) and titratable acidity, soluble solids, colour and L-ascorbic acid were measured on fresh berries. Phenolic samples then were kept frozen $\left(-27^{\circ} \mathrm{C}\right)$ in polyethylene bags $(3 \times 250 \mathrm{~g})$ until analysed.

Fruit colour was measured in a transmitted mode using a Konica Minolta CM-700d spectrophotometer. Measurements were conducted in the CIE L*a*b* system - the full nomenclature is 1976 CIE L*a*b* Space, International Commission on Illumination in Vienna $\left[\mathrm{L}^{*}\right.$ white $(100)$ black (0), a* green $(-100)$ red $(+100), b^{*}$ blue (-100) yellow (+100)] (HunterLab 2012), through a $10^{\circ}$ observer type and D65 illuminant, with the aperture diameter measuring $3 \mathrm{~mm}$. A handheld spectrophotometer equipped with photodiode array capturing the range $400-1100 \mathrm{~nm}$ was used for the non-destructive measurement of parameters (CP Pigment Analyzer PA1101 (produced by Control in Applied Physiology GbR., Germany). Spectra collected from CP PA1101 were used for calculating the Normalized Anthocyanin Index NAI $=(I 780$ - I570)/(I780 + I570) (Zude 2003).

Firmness and puncture resistance of the skin $\left(\mathrm{G} \mathrm{mm} \mathrm{m}^{-1}\right)$ was measured (in two axes of the fruit) with a FirmTech2 apparatus (BioWorks, USA), taken from 100 randomly selected berries from each replicate and expressed as a gram-force causing the fruit surface to bend $1 \mathrm{~mm}$. Punctures were made using a stamp with a diameter of $3 \mathrm{~mm}$. Weight loss during postharvest storage was determined by subtracting sample weights from their previous recorded weights and presented as $\%$ of weight loss compared to the initial weight.

To obtain juice, the berries (three replicates of $150 \mathrm{~g}$ ) were macerated at $50^{\circ} \mathrm{C}$ with the addition of 
the PT 400 Pektopol enzyme at a dose of $400 \mathrm{mg}$ per $\mathrm{kg}$ of fruits for 60 minutes. After the completion of the enzymatic processing, the pulp was pressed using a hydraulic press at a pressure of $3 \mathrm{MPa}$ (Oszmiański and Wojdyło 2005). Measurements were performed in triplicate. Soluble solids (\%) were determined with a PAL1 Konica Minolta refractometer. Titratable acidity $\left(\mathrm{g} 100 \mathrm{~mL}^{-1}\right)$ was determined by titration of the water extract of juice with $0.1 \mathrm{~N}$ $\mathrm{NaOH}$ to an end point of $\mathrm{pH} 8.1$ (measured with the Elmetron $501 \mathrm{pH}$ meter) recalculated as citric acid (PN-90/A-75101/04). L-ascorbic acid content (g 100 $\mathrm{mL}^{-1}$ ) was measured with an RQflex 10 reflectometer (Merck) (Ochmianet al. 2012). Total polyphenol content (mg $\left.100 \mathrm{~g}^{-1}\right)$ in the methanol (70\%) extracts was estimated according to Singleton and Rossi (1965) with the Folin-Ciocalteu reagent. The data is expressed as $\mathrm{mg}$ of gallic acid equivalents (GAE) per $100 \mathrm{~g}$ of fruit tissue.

In order to determine the significance of differences, a two-factor analysis of variance was carried out, followed by the assessment of the significance of differences using the Tukey' test. Differences between the means at $p=0.05$ were considered significant. The statistical analyses were performed using the Statistica software.

\section{RESULTS AND DISCUSSION}

Domestic fruits of highbush blueberries are only available for a short period of time; therefore, they are kept in storage to extend the period. Blueberry fruit can be stored in cold rooms for as long as eight weeks (Krupa and Tomala 2006). Post-harvest handling and storage conditions affect the quality of the fruits. Fruit firmness is considered to be a fruit quality indicator. Other quality indicators include fruit resistance to mechanical injuries during harvest, sorting, packing and transport. The research showed that both the rapid cooling of fruits after harvest and the conditions under which they are stored affect the investigated characteristics. Fresh fruits were found to be the most firm (both along the vertical axis [fruit height] and horizontal axis [fruit diameter]) and more resistant to damage (Tab. 1). Regardless of which method of storing or preparing for storage was selected, fruit firmness was adversely affected. Fruits kept in cold storage were found to be $17 \%$ less firm than the fresh fruits. During storage, highbush blueberries may become less firm than fresh fruits by up to a few dozen per cent (Yang et al. 2009). However, it was found that fruits pre-cooled after harvest and stored under controlled atmosphere conditions were firmer and more resistant to damage. This provides evidence that in the case of fruits, and in particular berry fruits, rapid cooling after harvest is crucial to obtaining positive results. This is also supported by the findings that the fruits that were subject to this process were characterised by lower weight loss during storage (1.5\%). Equally positive results were reported for fruits stored under controlled atmosphere conditions, with weight loss at a similar level (1.6\%). Fruits that were rapidly cooled after harvest and stored under CA (controlled atmosphere) conditions were the least affected in terms of weight loss. After six weeks of storage, the fruits lost $1.1 \%$ of their initial weight, while the

Table 1. Firmness and weight loss of Brigitta Blue cultivar highbush blueberry fruit following storage, depending on the method of storage preparation and storage conditions

\begin{tabular}{|c|c|c|c|c|c|}
\hline \multirow{2}{*}{$\begin{array}{l}\text { Preparation of fruit } \\
\text { (B) }\end{array}$} & \multirow{2}{*}{$\begin{array}{l}\text { Storage method } \\
\text { (A) }\end{array}$} & \multirow{2}{*}{$\begin{array}{c}\text { Puncture axis } \\
\text { diameter } \\
\left(\mathrm{G} \mathrm{mm}^{-1}\right)\end{array}$} & \multicolumn{2}{|c|}{$\begin{array}{l}\text { Firmness } \\
\left(\mathrm{G} \mathrm{mm}^{-1}\right)\end{array}$} & \multirow{2}{*}{$\begin{array}{c}\text { Mass loss } \\
(\%)\end{array}$} \\
\hline & & & axis diameter & axis height & \\
\hline fruit after harvest & & 112 & 197 & 394 & - \\
\hline \multirow{3}{*}{ not shock-cooled } & normal atmosphere & 73 & 164 & 355 & 3.18 \\
\hline & controlled atmosphere & 88 & 179 & 371 & 2.11 \\
\hline & mean & 80 & 171 & 363 & 2.65 \\
\hline \multirow{5}{*}{ shock- cooled } & normal atmosphere & 86 & 175 & 376 & 1.92 \\
\hline & controlled atmosphere & 107 & 191 & 383 & 1.08 \\
\hline & mean & 96 & 183 & 379 & 1.50 \\
\hline & normal atmosphere & 80 & 170 & 366 & 2.55 \\
\hline & controlled atmosphere & 98 & 185 & 377 & 1.60 \\
\hline \multirow{3}{*}{$\operatorname{LSD}_{p=0.05}$ for: } & Storage method (A) & 8 & 10 & 13 & 0.29 \\
\hline & Preparation of fruit (B ) & 9 & 12 & 15 & 0.37 \\
\hline & Interaction $(\mathrm{A} \times \mathrm{B})$ & 12 & 14 & 17 & 0.66 \\
\hline
\end{tabular}


Table 2. Chemical composition of Brigitta Blue cultivar highbush blueberries fruit depending on method of storage

\begin{tabular}{|c|c|c|c|c|c|}
\hline $\begin{array}{l}\text { Preparation of fruit } \\
\text { (B) }\end{array}$ & $\begin{array}{l}\text { Storage method } \\
\text { (A) }\end{array}$ & $\begin{array}{c}\text { Soluble solids } \\
(\%)\end{array}$ & $\begin{array}{l}\text { Titratable acidity } \\
\quad\left(\mathrm{g} 100 \mathrm{~mL}^{-1}\right)\end{array}$ & 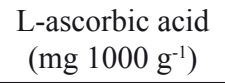 & 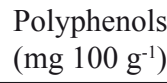 \\
\hline fruit after harvest & & 14.3 & 0.96 & 136 & 231 \\
\hline \multirow{3}{*}{ not shock-cooled } & normal atmosphere & 14.5 & 0.92 & 94 & 185 \\
\hline & controlled atmosphere & 14.2 & 0.95 & 117 & 204 \\
\hline & mean & 14.4 & 0.94 & 106 & 195 \\
\hline \multirow{5}{*}{ shock- cooled } & normal atmosphere & 14.4 & 0.94 & 125 & 197 \\
\hline & controlled atmosphere & 14.3 & 0.95 & 131 & 220 \\
\hline & mean & 14.3 & 0.95 & 128 & 209 \\
\hline & normal atmosphere & 14.5 & 0.93 & 110 & 191 \\
\hline & controlled atmosphere & 14.3 & 0.95 & 124 & 212 \\
\hline \multirow{3}{*}{$\operatorname{LSD}_{p=0.05}$ for: } & Storage method (A) & 0.1 & 0.09 & 9 & 12 \\
\hline & Preparation of fruit (B ) & 0.1 & 0.10 & 10 & 15 \\
\hline & Interaction $(\mathrm{A} \times \mathrm{B})$ & 0.2 & 0.13 & 12 & 18 \\
\hline
\end{tabular}

fruits stored in a conventional cold room without pre-cooling lost $3.2 \%$ of their initial weight. Fruit weight loss is caused by the loss of water. With an excessive loss of weight, the fruits lose their market value - they become shrivelled and withered. Weight loss also leads to significant financial losses. Losses in the mass of crops during storage depend on storage conditions as well as the type of blueberry. 'Brigitta Blue' fruits lost only $0.75 \%$ of their mass in the CA cold room (Alsmairat et al. 2011) in comparison to the conventional cold room, where losses reached 6.7\% (Chiabrando et al. 2009, Chiabrando and Giacalone 2011). After being stored for a few days in a conventional cold room, blue-berried honeysuckle fruits and strawberries lost $2.5 \%$ of their original weight (Ochmian et al. 2008, Ochmian 2007).

Vitamin C, i.e. ascorbic acid, is considered suitable for the treatment of many diseases (Verrax and Calderon 2008) and is important for the functioning of the human body, as it removes free radicals that inhibit metabolism (Linster and Van Schaftigen 2007). Polyphenols are of equal importance as they provide protection against free oxygen radicals, as well as UV radiation (Link et al. 2010). Freshly harvested berries were found to have the highest content of ascorbic acid (136 mg $1000 \mathrm{~g}^{-1}$ ) and polyphenolic compounds (231 mg $100 \mathrm{~g}^{-1}$ ) (Tab. 2). During storage, the amount of the ingredients in question had changed. The fruits kept in cold storage under CA and pre-cooled exhibited parameters similar to those of the fresh fruit (ascorbic acid $131 \mathrm{mg} 1000 \mathrm{~mL}^{-1}$, polyphenols

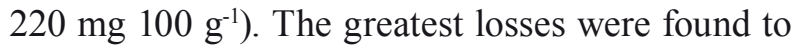
have occurred in fruits that were not subject to rapid cooling, and especially those stored in a conventional cold room. The degradation of ascorbic acid in food products is a widespread phenomenon and depends on many factors, including temperature and storage time (Martí et al. 2009, Santos and Silva 2008). Following a 12-month storage period in a frozen stage, the content of vitamin in the fruits decreased and ranged from 41 to $71 \mathrm{mg} 1000 \mathrm{~g} \mathrm{~g}^{-1}$, depending on the cultivar (Skupien 2006a). The vitamin content in the fresh fruits depends on the cultivar and cultivation techniques, but also on the ripening phase of the fruits, and may range from 71 to 279 mg $1000 \mathrm{~mL}^{-1}$ (Castrejón et al. 2008, Ochmian 2012). The content of anthocyanins in the fruit depends on the length of the storage period and the storage conditions. The extension of the period led to a decrease of anthocyanins (Krupa and Tomala 2006). Similarly, after a 12-month storage period in a frozen state, the polyphenol content in the fruits decreased, ranging from 218.7 to $307.5 \mathrm{mg} 100 \mathrm{~g} \mathrm{~g}^{-1}$ (Skupień 2006a).

However, the research did not provide any evidence to suggest that the storage conditions and the method of preparing fruits for storage had any significant impact on the soluble solids (14.2-14.5\%)

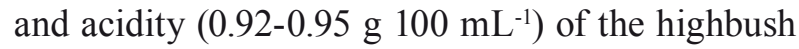
blueberry variety (Tab. 2). The lack of changes in soluble solids as well as in titratable acidity during the storage process was also noted by Chiabrando et al. (2009). Only the fruits that were stored in a conventional cold room showed an increase in the soluble solids, though it could have been caused by the biggest loss of water during storage, resulting in the concentration of the soluble solids. The amount of extract in blueberries depends on the cultivar and 
Table 3. Anthocyanin index and colour of Brigitta Blue cultivar highbush blueberries, depending on the method of storage preparation and storage conditions

\begin{tabular}{|c|c|c|c|c|c|}
\hline \multirow[b]{2}{*}{$\begin{array}{l}\text { Preparation of fruit } \\
\text { (B) }\end{array}$} & \multirow[b]{2}{*}{$\begin{array}{l}\text { Storage method } \\
\text { (A) }\end{array}$} & \multirow[b]{2}{*}{ NAI } & \multicolumn{3}{|c|}{ Colour CIE } \\
\hline & & & $\begin{array}{c}\mathrm{L}^{*} \\
\text { white }(100) \\
\text { black }(0)\end{array}$ & $\begin{array}{c}\mathrm{a}^{*} \\
\operatorname{green}(-) \\
\operatorname{red}(+)\end{array}$ & $\begin{array}{c}\mathrm{b}^{*} \\
\text { blue }(-) \\
\text { yellow }(+)\end{array}$ \\
\hline fruit after harvest & & 0.831 & 31.04 & 17.11 & -23.57 \\
\hline \multirow{3}{*}{ not shock-cooled } & normal atmosphere & 0.721 & 23.94 & 15.64 & -28.46 \\
\hline & controlled atmosphere & 0.778 & 27.58 & 14.27 & -25.83 \\
\hline & mean & 0.750 & 25.76 & 14.96 & -27.15 \\
\hline \multirow{5}{*}{ shock-cooled } & normal atmosphere & 0.793 & 28.62 & 18.35 & -26.79 \\
\hline & controlled atmosphere & 0.825 & 32.11 & 15.48 & -24.08 \\
\hline & mean & 0.809 & 30.37 & 16.93 & -25.44 \\
\hline & normal atmosphere & 0.757 & 26.28 & 17.00 & -27.63 \\
\hline & controlled atmosphere & 0.801 & 29.85 & 14.88 & -24.96 \\
\hline \multirow{3}{*}{$\operatorname{LSD}_{p=0.05}$} & Storage method (A) & 0.036 & 3.56 & 4.02 & 1.94 \\
\hline & Preparation of fruit (B ) & 0.039 & 3.84 & 4.27 & 2.17 \\
\hline & Interaction $(\mathrm{A} \times \mathrm{B})$ & 0.045 & 4.10 & 4.93 & 2.68 \\
\hline
\end{tabular}

may range from $11.7 \%$ to $19.7 \%$ (Skupień 2006b, Ochmian et al. 2009, Yang et al. 2009).

The colour of the fruit surface changed during storage. Change of colour mainly depends on storage conditions (Inaba and Crandall 1986, Kader and Ben-Yehoshua 2000). During storage, the fruits changed their peel colour, as defined by the following parameters: CIE L*a*b* (Tab. 3). During storage, the fruits darkened in colour compared to the fresh fruits, as demonstrated by the parameter value $\mathrm{L}^{*}$. These L* parameter cherries decreased during storage, mostly at room temperature (Gonçalves et al. 2007). When parameter value $b^{*}$ was on the increase, the fruit peal changed colour to blue due to an activity of the anthocyanin compounds. These changes were mainly caused by the lack of rapid cooling of the fruits and by the fact that the fruits were stored in a conventional cold room - the extent of changes increased. The research revealed that the value of the normalised anthocyanin index for these fruits had changed the most -0.721 (Tab. 3) - and that the fruits contained the smallest amount of total polyphenols - $185 \mathrm{mg}$ per $100 \mathrm{~g}$ (Tab. 2). NAI was also found to decrease during the storage of apples (Kuckenberg et al. 2008). A normalised anthocyanin index was used for the evaluation of apple peel anthocyanin content (Solomakhin and Blanke 2007). The present author's own research also showed that the normalised anthocyanin index used for highbush blueberries was highly correlated with the content of polyphenols $(r=0.83 *)$. Reque et al. (2014) found that during the long-term storage of blueberries, an average of $59 \%$ of anthocyanin compounds had degraded. This finding is also supported by the observations made by Krupa and Tomala (2006) that the content of polyphenol tends to decrease during the storage of blueberries.

\section{CONCLUSIONS}

1. To keep the high quality of highbush blueberries fruits, they must be immediately cooled after harvest and stored in a cold room with a controlled atmosphere. The fruits stored in a col d room under a controlled atmosphere were the least affected in terms of their firmness, content of ascorbic acid and polyphenolic compounds and mass loss. It was found that rapid cooling (pre-cooling) immediately after harvest had a positive influence on the fruits.

2. The storage period caused a decrease in the value of the normalised anthocyanins index, which was highly correlated with the polyphenol content. The anthocyanins index may be useful for the assessment of the content of polyphenolic compounds in fruits.

\section{ACKNOWLEDGEMENTS}

This work was supported by the Polish Ministry of Science and Higher Education under grant No. N N310 205337.

\section{REFERENCES}

Alsmairat N., Contreras C., Hancock J., Callow P., Beaudry R., 2011. Use of combinations of 
commercially relevant $\mathrm{O}_{2}$ and $\mathrm{CO}_{2}$ partial pressures to evaluate the sensitivity of nine highbush blueberry fruit cultivars to controlled atmospheres. HortSci. 46(1): 74-79.

Castrejón A.D.R., EichHolz I., Rohn S., Kroh L.W., Huyskens-Kei S., 2008. Phenolic profile and antioxidant activity of highbush blueberry (Vaccinium corymbosum L.) during fruit maturation and ripening. Food Chem. 109(3): 564-572.

Chiabrando V., Giacalone G., Rolle L., 2009. Mechanical behaviour and quality traits of highbush blueberry during postharvest storage. J. Sci. Food Agric. 89(6): 989-992.

Chiabrando V., Giacalone G., 2011. Shelf-life extension of highbush blueberry using 1-methylcyclopropene stored under air and controlled atmosphere. Food Chem. 126(4): 1812-1816.

Fallahi E., Conway W.S., Hickey K.D., Sams C.E., 1997. The role of calcium and nitrogen in postharvest quality and disease resistance of apples. HortSci. 32: 831-835.

Gonçalves B., Silva A.P., Moutinho-Pereira J., Bacelar E., Rosa E., Meyer A.S., 2007. Effect of ripeness and postharvest storage on the evolution of colour and anthocyanins in cherries (Prunus avium L.). Food Chem. 103(3): 976-984.

HäKkinnen S.H., KÄRENLAmpiS. O., MykKänen H.M., TÖRRÖNENA. R., 2000. Influence of domestic processing and storage on flavonol content in berries. J. Agric. Food Chem. 48: 2960-2965.

Hunterlab, 2012. Measuring Color using Hunter L, a, b versus CIE 1976 L*a*b*. AN 1005.00: 1-4. (www. hunterlab.com/an-1005b.pdf).

InABa M., CRAndall P., 1986. Cold-shock treatment of mature green tomatoes to delay color development and increase shelf-life during room temperature storage. Proc. Fla. State Hort. Soc. 99: 143-145.

Kader A., Ben-Yehoshua S., 2000. Effects of superatmospheric oxygen levels on postharvest physiology and quality of fresh fruits and vegetables. Postharvest Biol. Tec. 20(1): 1-13.

Krupa T., Tomala K., 2006. Effects of storage condition on anthocyanin content and antioxidative activity in highbush blueberries fruit. Żywn. Nauka Techn. Jakość 2(47): 171-181.

Kuckenberg J., Tartachnyk I., Noga G., 2008. Evaluation of fluorescence and remission techniques for monitoring changes in peel chlorophyll and internal fruit characteristics in sunlit and shaded sides of apple fruit during shelf-life. Post. Biol. Techn. 48(2): 231-241.

Link A., Balaguer F., Goel A., 2010. Cancer chemoprevention by dietary polyphenols: Promising role for epigenetics. Biochem. Pharmacol. 80: 17711792.

Linster C.L., Van Schaftigen E., 2007. Vitamin C, biosynthesis, recycling and degradation in mammals. FEBS Journal 274: 1-22.
Martí N., Mena P., Cánovas J.A., Micol V., Saura D., 2009. Vitamin $\mathrm{C}$ and the role of citrus juices as functional food. Natural product communications 4 : 591-748.

Moore J.N., 1993. Adapting low organic upland mineral soils for culture of highbush blueberries. Acta Hort. 346: 221-229.

Ochmian I., 2007. Influence of storage of fruits 'Senga Sengana' and 'Aga' strawberry cultivars on mass loss and firmness changes. Folia Univ. Agric. Stetin. Agric., Aliment, Pisc. Zootech. 259(4): 147-152.

Ochmian I., 2012. The impact of foliar application of calcium fertilizers on the quality of highbush blueberry fruits belonging to the 'Duke' cultivar. Not. Bot. Horti. Agrobo. 40(2): 163-169.

Ochmian I., 2013. The influence of cultivation conditions on the micro- and macronutrient content in the leaves and fruits of several cultivars of highbush blueberry. Folia Pomer. Univ. Technol. Stetin., Agric., Aliment., Pisc., Zootech. 305(27): 67-74.

Ochmian I., Grajkowski J., Skupień K., 2009. Influence of substrate on field and chemical composition of highbush blueberry fruit cv. 'Sierra'. J. Fruit Ornam. Plant Res. 17(1): 89-100.

Ochmian I., Grajkowski J., Skupień-Wysocka K., 2008. Field performance, fruit chemical composition and firmness under cold storage and simulated "shelf life" conditions of three blue honeysuckle cultigens (Lonicera caerulea). J. Fruit Ornam. Plant Res. 16: 83-91.

Ochmian I., Kozos K., Mijowska K., 2015. Influence of storage condictions on changes in physical parameters and chemical composition of highbush blueberry (Vaccinium corymbosum L.) fruit during storage. Bulg. J. Agric. Sci. 1: in press.

Ochmian I., Skupień K., Grajkowski J., Smolik M., Ostrowska K., 2012. Chemical composition and physical characteristics of fruits of two cultivars of blue honeysuckle (Lonicera caerulea L.) in relation to their degree of maturity and harvest date. Not. Bot. Horti. Agrobo. 40(1): 155-162.

Oszmiański J., WojdyŁo A., 2005. Aronia melanocarpa phenolics and their antioxidant activity. Eur. Food Res. Technol. 221: 809-813.

Remberg S.F., Rosenfeld H.J., Haffnier K., Gronnerod K., LEA P., 2006. Characterization of quality parameters of highbush blueberry (Vaccinium corymbosum L.) cultivars. Acta Hort. 715: 559-566.

Reque P.M., Steffens R.S., JABlonski A., FlôRes S.H., De O. Rios A., Jong E.V., 2014. Cold storage of blueberry (Vaccinium spp.) fruits and juice: anthocyanin stability and antioxidant activity. J. Food Compos. Anal. 33: 111-116.

Santos P.H.S., Silva M.A., 2008. Retention of vitamin $\mathrm{C}$ in drying processes of fruits and vegetables-A review. Drying Technology 26: 1421-1437. 
SingLeton V.L., Rossi JR. J.A., 1965. Colorimetry of total phenolics with phosphomolybdic-phosphotungstic acid reagents. Am. J. Enol. Vitic. 16: 144-158.

SKuPIEŃ K., 2006a. Evaluation of chemical composition of fresh and frozen blueberry fruit (Vaccinium corymbosum L.). Acta Sci. Pol., Hortorum Cultus 5(1): 19-25.

SkUPIEN K., 2006b. Chemical composition of selected cultivars of highbush blueberry fruit (Vaccinium corymbosum L.). Folia Hort. 18(2): 47-56.

Skupień K., Ochmian I., Grajkowski J., 2009. Influence of ripening on fruit chemical composition of two blue honeysuckle cultigens J. Fruit Ornam. Plant Res. 17: 101-111.

Solomakhin A.A., Blanke M.M., 2007. Overcoming adverse effects of hailnets on fruit quality and microclimate in an apple orchard. J. Sci. Food Agric. 87: 2625-2637.
STRIK B.C., 2005. Blueberry - an expanding world berry crop. Chron. Hortic. 45: 7-12.

Verrax J., Calderon P.B., 2008. The controversial place of vitamin $\mathrm{C}$ in cancer treatment. Biochem. Pharmacol. 76(12): 1644-1652.

WANG L., Sun D.W., 2001. Rapid cooling of porous and moisture foods by using vacuum cooling technology. Trends Food Sci. Tech. 12(5): 174-184.

Yang W.Q., Harpole J., Finn C.E., Strik B.C., 2009. Evaluating berry firmness and total soluble solids of newly released highbush blueberry cultivars. Acta Hort. 810: 863-868.

ZudE M., 2003. Comparison of indices and multivariate models to non-destructively predict the fruit chlorophyll by means of visible spectrometry in apple fruit. Anal. Chim. Acta. 481: 119-126.

Received September 15, 2014; accepted December 2, 2014 